\title{
Akut Pankreatit
}

\author{
Acute Pancreatitis
}

\section{Ayşegül Bükülmez ${ }^{1}$}

${ }^{1}$ Afyonkarahisar Sağlık Bilimleri Üniversitesi, Tıp Fakültesi, Çocuk Sağıı̆ı ve Hastalıkları Anabilim Dalı, Afyonkarahisar

Geliş Tarihi/Received: 2 Nisan 2019 Kabul Tarihi/Accepted: 6 Ekim 2019

Yazışma Adresi: Ayşegül Bükülmez, Afyonkarahisar Sağlık Bilimleri Üniversitesi, Tıp Fakültesi, Çocuk Sağlığı ve Hastalıkları Anabilim Dalı, Afyonkarahisar

e-mail: aysegulbukulmez@yahoo.com

\section{ORCID}

Ayşegül Bükülmez

https://orcid.org/0000-0002-6013-5172

\section{Öz}

Pankreatit son yıllarda çocuklarda artan sıklıkla gözlenen pankreas hastalığıdır. Erişkin ve çocuk pankreatitlerinin etiyoloji, epidemiyoloji ve risk faktörleri farklı olduğundan, hastalığın yönetimi ve tedaviye cevabı da farklı olmaktadır. Akut pankreatit, çocuklarda akut karın ağrısının acil tedavi gerektiren önemli bir sebebi olup kendi kendini sınırlayan, geri dönüşümlü sistemik inflamasyonla seyreden pankreasın inflamatuar hastalığıdır. Akut pankreatit tanısı INSPPIRE kriterlerine göre "pankreatit ile uyumlu karın ağrısı, amilaz ve/veya lipaz düzeyinin normalin üç katından yüksek olması ve radyolojik görüntülemede pankreatit ile uyumlu bulguların olması" kriterlerinden ikisinin olması ile konulmaktadır. Çocuklarda pankreatit etyolojisinde biliyer ve obstrüktif sebepler,sistemik hastalıklar, ilaçlar, travma, metabolik hastalıklar, idiyopatik sebepler rol oynamaktadur. Cocuklarda akut pankreatit genelikle hafif seyirli olup komplikasyonsuz iyileşmesine rağmen bazı olgularda tekrarlayan ataklarla seyreden akut rekurren pankreatite ilerleyebilir. Akut rekurren pankreatitinde kronik pankreatite ilerleme riski olduğundan erken tanınması önemlidir. Çocuklarda akut pankreatit tedavisinde genellikle destek tedavisi yapılmaktadır. Tedavide erken beslenme ve agresif uygun sıvı tedavisi, ağrı kontrolü oldukça önemlidir. Ayrıca komplikasyon gelişimi klinik olarak takip edilmelidir Ancak çocukluk çağı akut pankreatinin tanı ve tedavisinde çok merkezli standart tanı ve tedavi protokollerinin geliştirilmesine halen ihtiyaç duyulmaktadır.

Anahtar Kelimeler: Akut pankreatit, çocuk, tanı

\section{Abstract}

Pancreatitis is an increasingly common pancreatic disease in children in recent years. Since the etiology, epidemiology and risk factors of adult and pediatric pancreatitis are different, the management of the disease and its response to treatment are also different. Acute pancreatitis is an important cause of acute abdominal pain in children that requires urgent treatment and is a self-limiting, inflammatory pancreatic disease with reversible systemic inflammation. The diagnosis of acute pancreatitis is made according to the INSPPIRE criteria by having two of the criteria "abdominal pain compatible with pancreatitis, amylase and/or lipase level higher than three times normal and having findings compatible with pancreatitis in radiological imaging". Biliary and obstructive causes, systemic diseases, drugs, trauma, metabolic diseases, idiopathic causes play a role in the etiology of pancreatitis in children. Acute pancreatitis in children usually has a mild course and although it heals without complications, it may progress to acute recurrent pancreatitis with recurrent attacks in some cases. Early recognition is important in acute recurrent pancreatic as there is a risk of progression to chronic pancreatitis. Supportive treatment is generally used in the treatment of acute pancreatitis in children. Early nutrition and aggressive appropriate fluid therapy and pain control are very important in treatment. In addition, development of complications should be followed clinically. However, it is still necessary to develop multi-center standard diagnosis and treatment protocols in the diagnosis and treatment of acute pancreatitis in childhood.

Key words: Acute pancreatitis, children, diagnosis
Atıf yapmak için: Bükülmez A. Akut Pankreatit. Selcuk Med J 2020;36(4): 367373
Açıklama: Yazar bu makalede bahsedilen herhangi bir ürün, aygıt veya ilaç ile ilgili maddi çıkar ilişkisine sahip değildir. Araştırma, herhangi bir dış organizasyon tarafından desteklenmedi. Yazar çalışmanın birincil verilerine tam erişim izni vermek ve derginin talep ettiği takdirde verileri incelemesine izin vermeyi kabul etmektedir. 


\section{GíRiş}

Akut pankreatit (AP) son yıllarda insidansı giderek artmakta olan pediatrik acillerdendir. Çocukluk çağı akut pankreatiti etiyoloji, yönetim ve sonuçları hakkındaki bilgiler erişkin çalışmaları esas alınarak elde edilmektedir. AP pankreasın parankiminin geri dönüşümlü inflamasyonu olarak tanımlanır. AP pankreasta lokalize ödem, değişik derecelerde doku nekrozu ve organ hasarına neden olan sistemik inflamasyon ile karekterize bir hastalıktır. Patogenezi tam olarak anlaşılmamakla birlikte etiyolojisinde farklı nedenler vardır. Klinik olarak karın ağrısı ve serumda pankreas enzim yükseklikleri ile karekterizedir (1-3).

Erişkinlerde alkol ve biliyer etiyoloji ön planda iken, çocuklarda genetik, toksik, metabolik ve infeksiyoz nedenler ön plandadır. Vakaların \%15-30'u ise idiopatiktir. Erişkin ve çocukluk çağı pankreatiti arasında etyoloji ve risk faktörleri farklı olup hastalığın yönetimi ve tedaviye yanıt farklıdır (4).

Akut pankreatit tanısı Uluslararası Pediatrik Pankreatit Çalışma Grubu'na (INSPPIRE) göre konulmaktadır. Buna göre AP tanısı koymak için aşağıdaki 3 kriterden 2'sinin birlikte olması gerekir. Akut pankreatit ile uyumlu karın ağrısı, serum amilaz(<330 IU/L) veya lipaz (990 IU/L) değerinin üst sınırının normalden $\geq 3$ kattan fazla artması, ve akut pankreatit ile uyumlu (ödem veya hemoraji) görüntüleme yöntemlerinin olmasıdır (3).(Şekil 1)

\section{INSIDANS}

Akut pankreatit süt çocukluğu dahil tüm yaş gruplarında görülür. Çalışmalar son yirmi yılda akut pankreatit insidansının tüm yaş gruplarında artmış olduğunu göstermektedir. İnsidansdaki bu artışların çok faktörlü olduğu bilinmektedir. Bazı araştırmacılar acil servis başvurularında artış olması ve çocuk hastalarda pankreas enzimlerine bakılması ile ilişkilendirirken, diğerleri üçüncü basamak merkeze sevk edilme oranlarındaki artış ile ilişkili olduğunu bildirmişlerdir $(5,6)$.

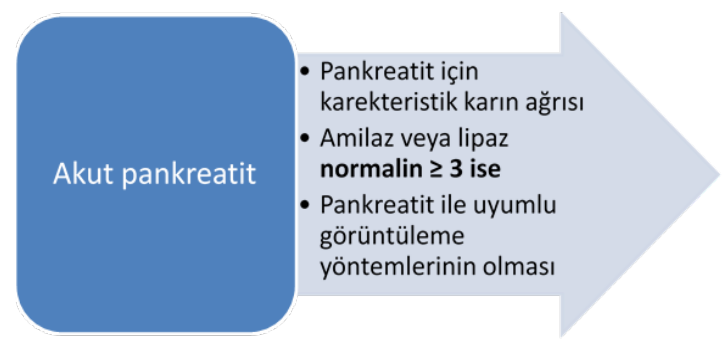

Şekil 1. Akut Pankreatit Tanı Kriterleri
Akut pankreatit insidansı son zamanlarda yılda 100000 'de 3,6-13,2 olup erişkin düzeylerine gelmiştir $(1,3)$. Akut pankreatit tüm yaş gruplarında görülmekle birlikte ortalama tanı yaşı 9 yaş (1 hafta-21yaş) olup erkek kız oranı 1:2 dir (7). Pant et al. ise akut pankreatiti 5 yaştan sonra (ortalama yaş 17 ) ve kızlarda erkeklere göre biraz daha fazla görüldüğünü bildirmişlerdir (8). Çocuklarda erişkinlerin aksine ciddi komplikasyon nadir olup çoklu organ yetmezliği ve pankreatik nekroz gelişme oranı \% 6'dan azdır. Pseudokist (\%10- 20) sıklıkla travmaya sekonder pankreatitlerde görülür. Çocuklarda mortalite oranları \%0-11 olup genellikle altta yatan hastalıkları mevcuttur $(5,9)$.

\section{ETIYOLOJi}

Erişkinlerde AP etiyolojisinde safra ve safra yolları ile ilişkili nedenler ve alkol kullanımı önemli rol oynamaktadır. Çocuklarda ise travma, ilaçlar, infeksiyonlar, toksinler, metabolik ve sistemik hastalıklar, pankreatobilier bileşke anomalileri ve genetik nedenler ile ilişkili olabilir $(2,4)$. Etiyoloji 6 kategoride incelendiğinde; \%24 idiopatik ve diğer nedenler, \%17 travma, \%15 sistemik hastalıklar, \%14 yapısal anormallikler, \%10 ilaçlar ve \%8 enfeksiyonlar olduğu görülmüştür $(4,5)$.

Illaçlar: L- asparaginaz, steroidler, valproik asid, azotiopurin ve meselazin.

Infeksiyonlar: Viral (Kabakulak, Kızamık, İnfluenza, Ebstein Barr virus),Bakteriler (Mikoplasma, Salmonella, Gram negatif bakteriler) Kabakulak infeksiyonu sonrası \% 0.3 -15 oranında pankreatit komplikasyon olarak görülebilir. Kabakulak infeksiyonuna bağlı pankreatitler ağır seyrederken, mikoplasma infeksiyonlarına bağlı olanlar hafif seyirli olabilir.

Konjenital anomaliler: Pankreatobilier sistem anomalileri arasında koledokal kist en sık nedendir. Annular pankreas, pankreas divisium, oddi sfinkter disfonksiyonu gibi anomaliler görülebilir.

Sistemik hastalıklar: Sistemik lupus eritematosus, poliarteritis nodosa, juvenil romatoid artrit, sepsis,çoklu organ yetmezliği, organ nakli, hemolitik üremik sendrom, Henoch schönlein purpurası, Kawasaki hastalığı, inflamatuar bağırsak hastalığı, kronik intestinal pseudoobstruksiyon, gastrik ülser, anoreksia nervosa, kistik fibrosis, besin alerjisi.

Metabolik: Hiperlipoproteinemi (I, IV, V), hiperkalsemi, diabetes mellitus, alfa 1 antitripsin eksikliği, metil malonik asidemi, propiyonik asidemi, ornitin karbomoil transferaz eksikliği

Beslenme: Malnutrisyon, yüksek kalorili beslenme, 
vitamin A ve D eksikliği

Diğerleri: Familyal, lenfoma, pseudopapiller neoplazmalar, idiopatik

Herediter pankreatitler: Herediter nedenler vakaların \%5- \%8 oranındagörülür. Otozomaldominant geçer. Katyonik tripsinojen genindeki (protease serin 1 PRSS1) mutasyon ile herediter pankreatit arasındaki ilişki 1996 yılında yayınlandı. Kronik idioapatik pankreatitle ilişkili Serin proteaz inhibitör gen (Kazal tip 1: SPINK1) 2000 yılında bildirildi. PRSS1 gen mutasyonuna bağı herediter pankreatit veya SPINK1 mutasyona bağlı tekrarlayan pankreatit atakları geçiren hastalarda gelecekte diabetes mellitus ve pankreatik ekzokrin yetmezlik gelişebilir. Bu hastalar ilerde pankreas kanserleri açısından riskli olabilirler. Ayrıca Kistik fibrosis transmembran regulatör gende (CTFR) vardır. Ayrıca 10 yaşına kadar akut pankreatit geçiren çocuklarda Karboksipeptidaz A1 ( CPA1) varyantı bildirilmiştir(4-12) Tablo 1 de akut pankreatit etiyolojisi görülmektedir.

\section{PATOFIZYOLOJi}

Pankreatit patofizyolojisinde birkaç faktör vardır. İlki geleneksel tripsine bağımlı teori (enzimlerin aktivasyonu pankreasta yıkıma neden olur), ikincisi inflamatuar yolak ( hayvan modelleri ile desteklenen), üçüncüsü endoplazmik retikulum stresidir (tripsin aktivasyonundan bağımsız). Normal koşullarda, sindirim enzimleri inaktif proenzimler (zimojen) olarak asiner hücrelerde sentezlenip salınırlar. Bu enzimlerin aktivasyonu duodenumda enterokinaz aracılığıyla başlar. Etiyolojisinden bağımsız olarak pankreatit patofizyolojisi asiner hücrelerde hasar ile başlar. Proteazlar, tripsin, elastaz, lipaz gibi diğer enzimler salınarak dokularda hasar yaparlar. pankreatik asiner hücrelerinde tripsinin düzensiz aktivasyonu sonucu oluşur. Pankreas sindirim enzimlerininin duodenum dışında aktivasyonunu başlatan olay tam olarak bilinmemektedir Asiner hücrelerde ilk olarak anormal fizyolojik olmayan kalsiyum kanalları oluştuktan sonra intraasiner pankreatik proenzimler veya zimojenler aktive olur. Pankreas içerisindeki enzim aktivasyonu pankreasta otodijesyona ve inflamasyona neden olur. Tripsinojen aktivasyonu engelleyen veya tripsin aktivitesini düşürmek için gerekli hücre içi koruyucu mekanizmaların baş edememesi sonucu gelişir. Asiner hücrelerdeki tripsinojen tripsine aktive olduktan sonra elastaz fosfolipaz A2 gibi enzimler kompleman ve kinin yolakları aktive olur. İnterlökin 1, interlökin 6 ve interlökin 8 gibi lokal mediatörler artar. Tümör nekroz faktör a salınır. Antiinflamatuar sitokinler (interlökin 10) azalır. Ayrıca endotelyal hücreler lökositlerin transendotelyal göçüne izin verir. Oksijen dağılımında azalma ve serbest radikallerin oluşumu pankreas hasarına neden olur. Olayı başlatan faktörden bağımsız olarak pankreas hasarının şiddeti asiner hücrelerin hasarı, inflamatuar ve endotelyal hücrelerin aktivasyonuna bağlıdır. Asiner hücre nekrozu, pseudokist formasyonu ve abse gibi lokal komplikasyonlar oluşabilir. Pankreas ve pankreas dışı karaciğer gibi organlardan salınan mediatörler akciğerler gibi uzak organlarda hasarlara neden olabilir. Pankreas ekzokrin fonksiyonlarının aşırı stimulasyonu sonrası pankreas sıvıları ve enterokinaz kaçışına bağlı olarak pankreatik kanal obstruksiyonu ve inflamasyon görülür $(1,3,5,12)$.

\section{TANI}

Akut pankreatit tanısı klinik bulgular, biyokimyasal testler ve görüntüleme yöntemleri değerlendirilerek konulur. Karın ağrısı erişkinlerdeki gibi çocuklarda da vakaların \% 80-95'inde en sık görülen semptomdur.

Tablo 1. Akut pankreatit etiyolojisi (21)

\begin{tabular}{ll}
\hline Sınıflama & Etyoloji \\
\hline Bilier & Koledok kisti, kolesistit, safra kesesi taşı, pankreas divisium, pankreatobilier bileşke \\
Sistemik & Şomalileri, tümör \\
& sendrom, kawasaki hastalığı, inflamatuar bağırsak hastalığı, poliarteritis nodosa, \\
& organ nakli, henoch-schönlein purpurası, kronik total parenteral beslenme \\
İlaçlar & Azatiopürin, merkaptopürin, prednizolon, meselamin, sitarabin, salisilik asit, \\
& indometazin, tetrasiklin, klorotiazid, izoniazid, antikoagülanlar, östrojen kullanımı \\
Travma & Abdominal travma, post ERCP, perfore gastrit veya duodenal ülser \\
Enfeksiyonlar & Kızamık, kabakulak, koksaki virüs, ekovirüs, influenza, Epstein-Barr virüsü, mikoplazma, \\
& Salmonella, hepatit A, Escherichia coli \\
Metabolik & Hiperlipidemi, hipertrigliseridemi, kistik fibrozis, diabetes mellitus, hiperkalsemi, \\
& Reye sendromu, renal hastalıklar, propiyonik asidemi, beslenme yetersizlikleri ve \\
& herediter pankreatit
\end{tabular}


Karın ağrısı lokalizasyonuna göre epigastrik (\%6289), yaygın karın ağrısı (\%12-20), sırt ağrısı (<\%10), dorsal bölgeye yayılan ağrı (\%1,6-5,6). İkinci en sık görülen semptom bulantı ve kusma vakaların \%4080, abdominal distansiyon \%21-46, Grey turner belirtisi ise \% 2 sinde bulunur. Diğer semptomlar ateş, sarılık, asit ve plevral efuzyondur. Süt çocuklarında abdominal distansiyon $\% 16$ ateş $\% 40$ olarak görülür $(1,4,5)$.

Ayırıcı tanı: Kolesistit, kolanjit, hepatit, diyabetik ketoasidoz, gastrik çıkış sendromu, intestinal infarkt, gastrik volvulus, perfore peptik ülser, tuba ovariyan abse ayırıcı tanıda düşünülmelidir.

\section{LABORATUVAR DEĞERLENDİRMESI}

Akut pankreatitde asiner hücrelerden dolaşıma pankreas enzimleri salınmaktadır. Akut pankreatit tanısında kullanılan başlıca biyokimyasal belirteçler serum amilaz ve lipaz'dır. Serum amilaz ve lipaz değerlerinin normalin 3 katından daha yüksek olması akut pankreatiti düşündürür. Karboksil ester lipaz, izoamilaz ve fosfolipaz A2 gibi diğer pankreas enzimlerinin henüz geçerliliği kanıtlanmamıştır. Serum kalsiyum, trigliseridler, transaminazlar, beyaz küre sayısı, üre nitrojeni, serum albumin düzeyleri de ölçülmelidir. Valproik asit ve L- asparaginaz kullanımına bağlı akut pankreatitlerde amilaz düzeyi özelikle çocuklarda normal bulunabilir. Lipaz primer olarak pankreastan salınırken diğer salınım yerleride gastrik ve lingual bölgedir. Akut pankreatitte lipaz semptomların başlangıcının ilk 6 saatinde artar, 2430 saatte serumda pik yaparak 1 haftadan daha uzun süre yüksek kalır. Serum lipazının sensitivitesi \%96,6 ve spesifitesi \% 78,6 iken serum amilazının spesifitesi $\% 78,6$ sensitivitesi $\% 99,1$ dir.Serum amilaz düzeyinin yarılanma ömrü serum lipaz düzeyinden daha kısadır. $\mathrm{Bu}$ nedenle serum lipaz düzeyleri pankreatitin geç dönemlerinden de ölçülebilir $(4,5,12)$.

Amilaz başlıca tükrük bezleri ve pankreastan salgılanır. Birçok laboratuvarda total amilaz düzeyleri ölçülür. Amilaz referans değerleri yaş,cinsiyet ve kullanılan labaratuvar testlerine göre değişebilir. Amilaz düzeyleri lipazdan daha önce yükselip, 24 saat içerisinde normale dönebilir. Bu nedenle pankreatitin geç tanısında kullanışlı bir belirteç değildir. Vakaların $\% 20$ sinde amilaz düzeyleri normal olabilir. Serum amilaz ve lipaz yükseklikleri pankreatit hariç renal hastalıklar, dekompansekaraciğeryetmezliği, bağırsak inflamasyonu (çölyak hastalığı ve inflamatuar barsak hastalığı, apandisit), karın ve baş travması, diyabetik ketoasidoz, tükrük bezi hastalıkları ve jinekolojik hastalıklarda yükselebilir. Ayrıca bazı bireylerde immunglobulinlerle birlikte büyük kompleks yapan amilaz ve lipaz makroamilazemi ve makrolipazemiye neden olabilir $(4,5,12)$.

\section{GÖRÜNTÜLEME ÇALIŞMALARI}

Başlangıçta öykü semptomlar, amilaz ve lipaz düzey yükseklikleri tanı koymak için yeterli ise erken fazda görüntüleme gerekli olmayabilir. Görüntüleme genellikle pankreatik nekroz, pankreatit komplikasyonları ve etiyolojiyi (safra kesesi taşı ve anatomik anormallikler) aydınlatmak için gereklidir (4).

Düz grafiler: Akut pankreatitte toraks grafisinde solda bazal atelektazi, diafragma yükselmesi ve plevral effüzyon saptanabilir. Ayakta direkt batın grafisinde ise spesifik bir bulgu yoktur. Pankreasın enflamasyonunun oluşturduğu lokal ileus ile duodenumda hava görüntüsü, jejunumda gaz gölgesinin olduğu "sentinel loop" ve kolonda sol tarafta hava görünümü yokken sağda tarafta görülen genişlik kolonik gazın olduğunu düşünderen "cut-off" belirtisidir. (1).

Abdominal Ultrasonografi: Akut pankreatitde ilk görüntüleme yöntemidir. Abdomen Ultrasonografide pankreas morfolojisi, pankreas kanalı ve ekstrapankreatik bulgulara dayandırılarak pankreatit tanısı konulur. Aynı zamanda altta yatan etiyolojiyi tanımlayabilir. Non-invaziv ve radyasyon içermemesi, kolay uygulanabilirliği avantajları olmasına rağmen obezlerde ve intraabdominal gaz varlığında pankreası değerlendirmede yeterli değildir $(1,4,12,13)$.

Abdomen Bilgisayarlı Tomografi: Abdomen Ultrasonografiden sonra ikinci olarak kullanılan görüntüleme yöntemidir. Genellikle serum belirteçlerinin henüz tam olarak yükselmediği, semptomların şüpheli olduğu durumlarda çekilebilir. İdeal olarak semptomların başlangıcının 96. saatinde çekilmesi önerilir. Peripankreatik sıvı birikimi veya pseudokist ayrımını yapabilir. Hastanın klinik durumunun kötüleştiğinde veya semptomların şiddetlendiği durumlarda çekilebilir $(4,12,13)$. Lautz et al. geliştirdiği bilgisayarlı tomografi şiddet indeksi (Balthazar skoru) akut pankreatit şiddetinin değerlendirilmesinde kullanılabilir (14).

Manyetik Rezonans Görüntüleme (MRG): İyonize radyasyon gerektirmemesi, iodine kontrast madde alerjisi olan hastalarda kullanım olanağı, çok kesitli görüntüler alması nedeniyle pankreatobilier anomalileri göstermek için iyi bir tercihdir. Ayrıca gebelerde ve böbrek yetmezliği olanlarda, intravenöz 
kontrast madde alerjisi olanlarda kullanılabilir. Özellikle doku nekrozunu göstermede bilgisayarlı tomografiden daha hassastır $(4,12,13)$.

Manyetik Rezonans Kolanjiopankreatografi (MRCP): Pankreatitin biliyer etyolojisini aydınlatmada önemlidir. MRCP'nın ideal çekilme zamanı pankreas ödeminin gerileyip akut atağın yatıştığı dönemdir $(4,12,13)$.

Endoskopik Retrograd Kolanjio Pankreotografi (ERCP) ve Endoskopik USG: Endoskopik Retrograd Kolanjio Pankreotografinin AP'de kullanımı sınırlı olup deneyim gerektirmektedir. Etiyolojinin bulunamadığı durumlarda tercih edilebilir. Biliyer pankreatite neden olan koledokolitiazis, pankreatik kanal patolojilerine bağlı pankreatitlerde endikedir. Çocukluk çağı AP'lerinde EUS kullanımı standart olarak önerilmez. Seçilmiş vakalarda kullanılabilir $(4,12,13)$.

\section{DERECELENDIRME}

Çocuklarda AP'de henüz kesin olarak kabul edilmiş skorlama sistemi yoktur. Erişkinlerde Ranson kriterleri, modifiye Glasgow skalası, APACHE II indeksi kullanılırken çocuklarda kullanımının bazı kısıtlamaları vardır. Çocukluk çağı pankreatitlerinde ilk olarak 2002'de De Banto tarafından geliştirilen pediatrik akut pankreatit şiddet skoru (PAPS) kullanılmaya başlandı (15). Kullanılan parametreler: Yaş(<7), kilo(<23kg), Beyaz küre sayısı (>18500/ $\left.\mathrm{mm}^{3}\right), \mathrm{LDH}(>2000 \mathrm{IU} / \mathrm{L}), 48$ saatte $\mathrm{Ca}+(<8,3 \mathrm{mg} /$ $\mathrm{dL})$, albumin $(<2,6 \mathrm{~g} / \mathrm{dL})$, sıvı sekestrasyonu( $>75 \mathrm{ml} /$ $\mathrm{kg} / 48$ saat)ve 48 . saatte BUN'da artış (>5 mg/dL) (15) Suzuki et al. geliştirmiş olduğu 9 parametreden oluşan Pediatrik JPN skorlama sisteminin geniş pediatrik populasyona uygulanması konusunda fikir birliği yoktur. (1) Pediatrik JPN skorlamasının parametreleri ise: baz eksiği $\leq 3$ meq veya şok (sistolik kan basıncına göre), (2) $\mathrm{PaO}_{2} \leq 60 \mathrm{mmHg}$ veya sonum yetmezliği (3) BUN $\geq 40 \mathrm{mg} / \mathrm{dL}[$ Kreatinin $\geq 2.0 \mathrm{mg} / \mathrm{dL}$ ] veya oligüri $(<0.5 \mathrm{~mL} / \mathrm{kg} / \mathrm{saat}(4) \mathrm{LDH} \geq 2 X$ Üst limit (5) trombosit sayısı $\leq 1 \times 10^{3} \mathrm{~mm} 3(6)$ Kalsiyum $\leq 7.5$ $\mathrm{mg} / \mathrm{dL}(7) \mathrm{CRP} \geq 15 \mathrm{mg} / \mathrm{dL}$, Pediatrik SIRS skoru $\geq 3$ (9)Yaş<7, ve/veya kilo 23 kg (16)

Skorlamalardaki sensitivite ve spesifiteler sırasıyla şu şekildedir: Pediatrik JPN skorlaması (\%80;\%96), Ranson (\%60;\%94), modifiye Glasgow (\%50;\%99) ve De Banto (\%60;\%86). Buna göre akut pankreatitli vakalarda JPN skorlaması daha güvenilir kabul edilebilir (16).

Bilgisayarlı tomografi şiddet indeksi (Balthazar skoru) akut pankreatitli çocuklarda kullanılmaktadır. Ancak çocuklarda AP'de BT rutin olarak çekilmediği için her vakada kullanılması mümkün olmamaktadır(14). Ayrıca lipaz düzeyinin 7 katından fazla olması skorlama sistemi olarak AP'de kullanılmakta olup sensitivitesi $\% 85$, spesifitesi $\% 54$ 'tür $4,15,17$ ).

Çocuklarda AP klinik olarak Atlanta Kriterlerine göre hafif, orta ve ağır olmak üzere üç grupta sınıflandırılmaktadır. Hafif AP'de organ yetmezliği, lokal ve sistemik komplikasyonlar yoktur. Orta şiddetli AP'de 48 saat'den az süren geçici organ yetmezliği ve/veya lokal veya sistemik komplikasyonlar eşlik eder. Bir hafta içinde düzelir. Ağır AP'de ise tekli veya çoklu organ yetmezliğinin eşlik ettiği 48 saatten uzun süren kalıcı organ yetmezliği eşlik etmektedir(18).

\section{TEDAVi}

Çocuklarda AP tedavisi erişkinlerdekine benzer şekilde yapılmaktadır. AP tedavisinde amaç pankreastan ekzokrin sekresyonları azaltmak için oral SıVı ve besin alımını keserek pankreası dinlendirmektir. Sıvı ve elektrolit tedavisi, beslenme yönetimi,enzim inhibisyon tedavisi, ağrı tedavisi ve enfeksiyon ve tromboembolik olayları önlemek önemlidir $(4,6,12)$.

Sıvı tedavisi: AP'de intravenöz sıvı tedavisi başlıca tedavidir. Pankreatitde çevre dokulara inflamasyona sekonder sıvı kaçışı olduğundan hücre dışı sıvıyı desteklemek için sıvı tedavisi önemlidir. Akut pankreatitte sıvı tedavisi sadece hipovolemiyi düzeltmekle kalmaz aynı zamanda yeterli perfüzyon sağlayarakpankreatikmikrosirkülasyonunbozulmasını önleyerek mikrotrombüs oluşumunu engeller.Böylece pankreatitte komplikasyon gelişmesini ve hastalığın ilerlemesini engellemektedir $(4,6,12)$.

Çocukluk çağı akut pankreatit tedavisinde kullanılan sıvının içeriği konusunda tam bir fikir birliği olmamakla birlikte Szabo et al. ilk 24 saatte \%5 dekstrozlu serum fizyolojiğin güvenilir ve iyi tolere edilen bir seçenek olduğunu önermiştir.Ayrıca verilecek sıvı miktarının normalin 1,5-2 katı kadar olması gerektiğini yaptığı çalışmada belirtilmişlerdir(19).

Ağrı Yönetimi: Akut pankreatit'de en sık görülen semptom karın ağrısıdır. Çocukluk çağı AP çalışmalarında karın ağrısı olup hastaların \%8095'inde görülür. Bu hastalarda ağrı \% 62-89'u epigastrik, \% 12-20'sinde diffüz, \% 1,6-5,6'sında sırta vuran ağrı şeklindedir. Ağrı kontrolü AP tedavisinde önemli olup periferik ya da santral etkili analjeziklerle yapılır $(4,5,12)$.

Opioid Analjezikler: AP'de ağrı çok şiddetli olup sıradan analjezikler yetersiz kalır. Morfin veya benzeri opioidler kullanılır. Morfinin sistemik alımından sonra oddi sfinkter disfonksiyonu yapabileceği bilinse de 
AP hastalarında halen kullanılabilmektedir. Morfinin kontrendike olduğuna dair çalışmalar yoktur. Başlıca kullanılan opioid analjezikler meperidin, fentanil, pentazosin, petidin ve buprenorfindir $(12,20)$.

Diğer analjezikler: Nonsteroid antiinflamatuarların AP gelişiminde potansiyel katkıları olduğu bilinmesine rağmen $A P$ ağrı yönetiminde de faydalı olduğu bilinmektedir. İndometazin ve diklofenak gibi nonsteroid antiinflamatuarların ERCP sonrası gelişen pankreatiti önlemek amacı ile kullanımı önerilmektedir. Prokain gibi lokal anesteziklerin kullanımı AP analjezisi için önerilmektedir (12). Epidural anestezi özellikle sempatik sinir blokajı yaparak,splenik kan akımının yeniden dağılımını ve perfüze olmayan pankreatit bölgelerinin perfüzyonunu sağlayarak analjezi sağlamaktadır (4).

Sekresyon azaltan ilaçlar: Proteaz inhibitörlerinin çocuklarda kullanımı ile ilgili kesin bir kanıt yoktur. Somatostatin anologları ekzokrin pankreas sekresyonlarının ve kolesistokinin güçlü bir inhibitörüdür. Vaka raporları düzeyinde octreotidin pankreatitin komplikasyonu olan pseudokist tedavisi ve ilaca bağlı pankreatitin önlenmesinde ve tedavisinde etkili olduğu bildirilmiştir(1).

\section{Beslenme:}

Oral ve enteral beslenme: Geleneksel olarak AP'li hastalarda barsağın dinlenmesinin pankreasın dinlenmesini sağlayarak iyileşmeyi hızlandırdığı hipotezine dayandırılarak genellikle non-peroral veya parenteral beslenme şeklinde tedavi edilirlerdi. Buna karşılık günümüzde enteral beslenmenin parenteral beslenmeye göre daha avantajlı olduğu gösterilmiştir. Enteral beslenmenin en kısa sürede başlanması bakteriyal translokasyonu ve komplikasyon gelişimi açısından önemlidir. Enteral beslenmeye ilk 48 saat içerisinde başlanan AP'li olgularda mortalite, enfeksiyon ve çoklu organ yetmezliğinin belirgin azaldığı ve ilk 72 saat içerisinde enteral beslenmeye başlamanın aktif tedavi edici bir yaklaşım olduğu bildirilmiştir $(4,12)$.

Tam enteral beslenme ağrı ve besin intoleransı nedeniyle mümkün olamadığından, enteral nutrisyon ve parenteral nutrisyonun birlikte başlanılması önerilebilir. Parenteral ve enteral nutrisyonun birlikte kullanımı komplikasyon ve hastanede kalma süresini azaltmaktadır. Enteral beslenme gastrik ve jejunal olabilir. Enteral beslenmede semi-elimenter ve polimerik formula kullanılabilir $(2,4,12)$.

Antibiyotik proflaksisi: Rutin olarak önerilmez. Profilaktik kullanımı tartışmalı olmakla birlikte steril nekrotizan pankreatitin enfekte nekrotizan pankreatite dönüşümünü engellemek amacıyla imipenem ve veya 3 . kuşak sefalosporinler kullanılabilir. Nekrotizan pankreatitte ise kinolonlar, karbapenem ve metronidazol önerilmektedir $(1,2,4)$.

Proteaz inhibitörleri: Erişkinlerde gabeksat mezilat ve tripsin inhibitör aprotinin gibi antiproteaz kullanımına ait çalışmalar olsa da kullanımları hakkında öneri yoktur. Çocuklarda ise kullanımları asla önerilmez (4).

Antioksidanlar: Askorbik asit, $\beta$ karoten, $\alpha$ tokoferol gibi vitaminler selenyum ve glutamin başlıca antioksidanlardır. Erişkinlerde potansiyel yararları bilinsede çocukluk çağında kullanılmasına dair veriler yeterli değildir(4).

Probiyotiklerin rolü: Çocukluk çağı pankreatitlerinde probiyotiklerin kullanımı ile ilgiliyeterli çalışma olmaması nedeniyle kullanımı önerilmez. Bir erişkin çalışmasında probiyotiklerin yararından çok zararı olabileceğine dair bilgiler yer almaktadır (4).

Cerrahi tedaviler: Akut Pankreatit genellikle medikal olarak tedavi edilmekle birlikte bazı vakalarda endoskopik cerrahi tedavi gerekebilmektedir. ERCP akut pankreatitin özellikle biliyer nedenli olanlarında kullanılmaktadır. Pankreatik pseudokistler pankreatik kanal hasarına bağlı olarak sıvı ekstravazyonu sonucu pankreatit başlangıcından 4 hafta sonra oluşabilir. Pseudokist boyutu değişmiyor veya infeksiyon hemoraji gibi komplikasyon oluşuyorsa tedavisi drenaj veya nekrozektomi olup Endoskopik ultrason veya ERCP yardımı ile yapılabilir (4).

\section{KOMPLIKKASYONLAR}

Erken ve geç olmak üzere ikiye ayrılmaktadır. Erken komplikasyonlar hipovolemik ve septik şok, renal yetmezlik, asit, plevral efüzyon ve akut respiratuar distres sendromudur. Akciğer ve böbrek komplikasyonlardan etkilenen başlıca iki organdır (5). Geç komplikasyonlar erişkinlere göre çocuklarda daha nadir görülür. Başlıca steril ve enfekte kolleksiyonlar, fistül, vasküler konplikasyonlar (tromboz ve pseudoanevrizma) gelir. Çocuklarda en sık görülen komplikasyon pseudokist oluşumudur (4).

Çocuklarda erişkinlerin aksine ciddi komplikasyon nadir gelişir. Çoklu organ yetmezliği ve pankreatik nekroz gelişme oranı çocuklarda \% 6'dan azdır. Pseudokist oluşumu sıklığı \% 10-20 olup sıklıkla travmaya sekonder pankreatitlerde görülür. Çocuklarda mortalite oranları \%0-11'dir (5). Komplike olmayan pseudokist seri ultrasonografi çekimleri ile konservatif olarak takip edilir. Enfekte veya kanamalı komplike pseudokistler için drenaj ve antibiyoterapi 
gerekli olabilir. Akut pankreatitli çocukların \%15-35'i akut rekürren pankreatite ilerleyebilir (9).

Çocuklarda genellikle altta yatan hastalığı olanlarda mortalite görülmektedir. Erişkinlere göre çocuklarda mortalitenin az olması koruyucu mekanizmaların olduğunu düşündürmektedir. Erişkinlerde olmayan bu koruyucu mekanizmaların keşfi akut pankreatit tedavisinde faydalı olacaktır. Erişkin ve çocukluk çağı pankreatit etyolojisinin farklı olması, erişkin ve çocuklar arasındaki fizyolojik farklılıklar ve erişkinlerdeki ekstrapankreatik hastalıkların birlikteliği iki grup arasındaki mortalite farklılıklarının temel sebeplerindendir (5).

\section{IZLEM}

Taburcu edilmeden önce hastaların elektrolit anormalliklerinin düzeltilmesi, ağrı kontrolünün sağlanması ve enteral beslenmenin tolere edilebilir olması gereklidir. Taburculuk sonrası hastalar pseudokist gibi komplikasyonlar açısından yakından takip edilmelidir. Hastalar ilk ataktan 4-6 hafta sonra şiddetli ve tekrarlayan karın ağrısı ile başvurduğunda pseudokist açısından dikkatli olunmalıdır. Pankreatit gelişimini öngören tarama testi henüz mevcut değildir. Sadece spesifik etiyolojiye yönelik pankreatit gelişimi öngörülebilir (21).

\section{SONUÇ}

Akut pankreatit son yıllarda artan sıklıkta görülen ve çocuk hekimlerinin farkındalığının arttığı bir hastalıktır. Buna karşılık AP'lere yaklaşım halen hekimin deneyimi ve erişkin AP'lerinden kazanılan bilgilere göre yapılmaktadır. Ancak çocukluk çağı pankreatit kılavuzlarının eksikliği halen devam etmektedir. $\mathrm{Bu}$ nedenle çocukluk çağı akut pankreatitlerinde çok merkezli standart tanı ve tedavi protokolleri geliştirilmelidir.

Çıkar Çatışması: Çalışmada herhangi bir çıkar çatışması yoktur.

Finansal Çıkar Çatışması: Çalışmada herhangi bir finansal çıkar çatışması yoktur.

Yazışma Adresi: Ayşegül Bükülmez, Afyonkarahisar Sağlık Bilimleri Üniversitesi, Tıp Fakültesi, Çocuk Sağlığı ve Hastalıkları Anabilim Dalı, Afyonkarahisar, Türkiye

e-mail: aysegulbukulmez@yahoo.com

\section{KAYNAKLAR}

1. Sathiyasekaran M, Biradar V, Ramaswamy G, et al. Pancreatitis in children. Indian J Pediatr 2016;83(1213):1459-72.

2. Husain SZ, Srinath AI. What's unique about acute pancreatitis in children: Risk factors, diagnosis and management. Nat
Rev Gastroenterol Hepatol 2017;14(6):366-72

3. Morinville VD, Husain SZ, Bai H, et al. INSPPIRE Group. Definitions of pediatric pancreatitis and survey of present clinical practices. J Pediatr Gastroenterol Nutr 2012;55(3):261-5.

4. Abu-El-Haija M, Kumar S, Quiros JA, et al Management of acute pancreatitis in the pediatric population: A clinical report from the NorthAmerican society for pediatric gastroenterology, hepatology and nutrition pancreas committee. J Pediatr Gastroenterol Nutr 2018;66(1):159-76

5. BX Harrison, Lowe ME, Sohail $\mathrm{ZH}$, et al. What have we learned about acute pancreatitis in children? J Pediatr Gastroenterol Nutr 2011;52(3):262-70.

6. Uc A, Fishman DS. Pancreatic disorders. Pediatr Clin North Am 2017;64(3):685-706.

7. Yeo M, Kirkham S. Paediatric pancreatitis. Paediatr Child Health Paediatrics and Child Health 2017;27(12):561-6.

8. Pant C, Deshpande A, Olyaee M, et al. Epidemiology of acute pancreatitis in hospitalized children in the United States from 2000-2009. PLoS One 2014; 9:e95552

9. Della CC, Faraci S, Majo F, et al. Pancreatic disorders in children: New clues on the horizon. Dig Liver Dis 2018;50(9):886-93.

10. Pohl JF, UcA. Paediatric pancreatitis. Curr Opin Gastroenterol 2015;31(5):380-6.

11. Uc A, Husain SZ. Pancreatitis in children. Gastroenterology 2019;156(7):1969-78.

12. Wyllie R, Hyams JS, Kay M. Pediatric Gastrointestinal and Liver Disease. In: Pancreatitis.Philadelphia: Elsevier 2016:1016-1026.e5

13. Restrepo R, Hagerott HE, Kulkarni S, et al. Acute pancreatitis in pediatric patients: Demographics, etiology, and diagnostic imaging. AJR Am J Roentgenol 2016;206(3):632-44.

14. Lautz TB, Turkel G, Radhakrishnan J, et al. Utility of the computed tomography severity index (Balthazar score) in children with acute pancreatitis. J Pediatr Surg 2012;47:118591.

15. Debanto JR, Goday PS, Pedroso MR, et al. Acute pancreatitis in children. Am J Gastroenterol 2002;97:1726-31.

16. Suzuki M, Saito N, Naritaka N, et al. Scoring system for the prediction of severe acute pancreatitis in children. Pediatr Int 2015;57(1):113-8.

17. Coffey MJ, Nightingale S, Ooi CY, et . Serum lipase as an early predictor of severity in pediatric acute pancreatitis. J Pediatr Gastroenterol Nutr 2013;56(6):602-8.

18. Abu-El-Haija M, Kumar S, Szabo F, et al. Classification of acute pancreatitis in the pediatric population: Clinical report from the NASPGHAN Pancreas Committee. J Pediatr Gastroenterol Nutr 2017;64(6):984-90.

19. Szabo FK, Fei L, Cruz LA, et al. Early enteral nutrition and aggressive fluid resuscitation are associated with improved clinical outcomes in acute pancreatitis. J Pediatr 2015;167(2):397-402 e1.

20. Basurto OX, Rigau CD, Urrutia G, et al. Opioids for acute pancreatitis pain. Cochrane Database Syst Rev 2013;(7):CD009179.

21. Shukla-Udawatta M, Madani S, Kamat D. An update on pediatric pancreatitis. Pediatr Ann 2017;46(5):e207-e11. 